\title{
Fragmentation and vulnerability in Anne Enright's The Green Road (2015): Collateral casualties of the Celtic Tiger in Ireland
}

\author{
MARIA AMOR BARROS-DEL RÍO* \\ Universidad de Burgos (Spain)
}

Received: 14/12/2016. Accepted: 26/05/2017.

\begin{abstract}
This article explores the representation of family and individuals in Anne Enright's novel The Green Road (2015) by engaging with Bauman's sociological category of "liquid modernity" (2000). In The Green Road, Enright uses a recurrent topic, a family gathering, to observe the multiple forms in which particular experiences seem to have suffered a process of fragmentation during the Celtic Tiger period. A comprehensive analysis of the form and plot of the novel exposes the ideological contradictions inherent in the once hegemonic notion of Irish family and brings attention to the different forms of individual vulnerability, aging in particular, for which Celtic Tiger Ireland has no answer.
\end{abstract}

KEYWORDS: Anne Enright, The Green Road, Ireland, contemporary fiction, Celtic Tiger, mobility, fragmentation, vulnerability, aging.

\section{INTRODUCTION}

Ireland's central decades of the $20^{\text {th }}$ century featured a nationalism characterized by selfsufficiency and a marked protectionist policy. This situation changed in the 1960s and 1970s when external cultural influences through the media, growing flows of migration and economic transformations initiated by the government, together with the weakening of the Welfare State, progressively transformed a rural new-born country into an international

*Address for correspondence: María Amor Barros-del Río. Departamento de Filología. Facultad de Humanidades y Comunicación. Paseo de los Comendadores s/n. 09001. Universidad de Burgos, Spain; e-mail: abarros@ubu.es 
power (Fagan, 2003; Kennedy, 1989; Kirby, 2004; Morales-Ladrón \& Elices-Agudo, 2016; Smyth, 2012; White, 2008). A turning point was when in 1973 Ireland joined the European Economic Community (EEC). Commercial and ideological boundaries began to break down and during the last decades of the $20^{\text {th }}$ century, a progressive open market spurred by American information technology and pharmaceutical corporations' investments gave way to globalization and the Celtic Tiger phenomenon in Ireland. This caused an undeniable change in the cultural and ideological foundations of the Irish Republic. The Celtic Tiger period took place from the mid-1990s to mid-2000s in its first phase and from 2004 to 2008 in its second boom. As expected, the complex articulations between political, economic and cultural factors inherent to these episodes made an impact on Irish people's lives (Fagan, 2003; Mays, 2005). Contemporary Irish literature has witnessed these changes engaging in a variety of discourses and experiences that challenge the $20^{\text {th }}$ century traditional construction of "Irishness". Among others, authors such as John McGahern, Colum McCann, Anne Haverty, Roddy Doyle, Éillís Ní Dhuibne, Patrick McCabe, and Anne Enright have explored these transformations from different perspectives in the novel form (Cahill, 2011; Estévez-Saá, 2010 \& 2013; Hand, 2011; McGlynn, 1999; Morales-Ladrón \& Elices-Agudo, 2016). In particular, Enright's novel, The Green Road (2015), ${ }^{1}$ focuses on the troubled relations among the members of the Madigan clan and how they feel as affected by the circumstances of their separated lives as they do by the economic boom Ireland was undergoing during the Celtic Tiger period.

The object of this study is to bring to the fore the treatment given to the neoliberal context that frames the plot in order to assess how globalization has affected the concepts of individual, family and home in Irish culture represented in The Green Road. Therefore, the exploration of the intimate relation between subject, mobility and the political and economic structures that shape both individual and collective subjectivity (D'Andrea, Ciolfi \& Gray, 2011) is at the core of this paper. Supported by the sociological category of "liquid modernity" proposed by Bauman (2000), this analysis discloses the ideological contradictions inherent in the Irish notion of family. A special focus on the social and emotional consequences of globalization highlights the structural patterns of collective fragmentation that The Green Road contemplates. Finally, this study brings attention to the emotional tensions derived from the economic changes and how they elicit different forms of individual vulnerability for which Celtic Tiger Ireland has no answer. 


\section{ANALYSIS}

\subsection{A fractured novel for fluid times}

Emigration has been a characteristic Irish feature before and after the Celtic Tiger period, and to this day it still plays a prominent role in the Irish economy, culture and history (Fitzgerald \& Lambkin, 2008; Gilmartin \& White, 2008). But during the economic boom, mobility flows were reversed and Ireland witnessed an unprecedented inward migration tendency. ${ }^{2}$ These fluctuations have affected the relation individuals establish among themselves and with their families and homes as space and mobility are parameters that alter the physical and emotional ties that people build with their kinship and place of origin. These issues have been subsumed in Bauman's sociological category of "liquid modernity" (2000). According to his proposal, globalization has modified the relation between time and space. These two essential elements in human life used to hold a predictable and stable relation that allowed people to foresee, predict and to a certain extent, decide about their place in the world. Recently, that relation has become not only dialogical and variable but also unpredictable and independent of human control. In other words, what was once solid and reliable is not anymore. Thus, some consequences of the growing fluidity and mobility intrinsic to the process of globalization are disengagement and disintegration of social networks and human bonds (Bauman, 2000: 14). This acquires a particular meaning in the Irish context where land and family had been two normative pillars upon which the newborn nation had taken shape in the central decades of the $20^{\text {th }}$ century (Gray, 1999; Hanafin, 2001; Örmengül, 2015). But as Bauman affirms, "today's modern states have passed from the nation-building stage into that of multicultural belonging" (2011: 425). In fact, with the advent of globalization and more particularly during the Celtic Tiger years, the old concepts were reformulated both by public and official discourses and by the actual performances of transient humans who had to adapt to modernity. As a result, the thread that links the local and the global, the past and the present, the tradition and the innovation is stretched by negotiations that come at a price. Brittleness and vulnerability can be counted as collateral damages.

These tensions are masterly portrayed in The Green Road, where Anne Enright looks at this socioeconomic context with an unexpected degree of intimacy and harshness. Comprising the story of Rosaleen Madigan and her four children, the novel glimpses at a span of twenty-five years (1980-2005) and flies over three continents. Formally, the novel is divided into two distinctive parts. Part one is entitled "Leaving", where the reader is embarked on a trip around the world with stops at different times and places. Each chapter included in this part is entitled after the characters' names followed by the place and time of each story: "Hanna in Ardeevin, Co. Clare, 1980", "Dan in New York 1991", "Constance in Co. Limerick, 1997", "Emmet in Ségou, Mali, 2002" and "Rosaleen back in Ardeevin, 2005". It all makes a mosaic of five people in three continents, an allegory of the dispersal of 
the Irish in the $20^{\text {th }}$ century. Part two is entitled "Coming Home" and is set in 2005. It revolves around a Christmas family meeting at the Madigan's home located in a small village on the west coast of County Clare. There, the matriarch, Rosaleen, summons her four children who feel obliged to gather at her call. This second half of the novel is formally organized in chapters, some of which are also entitled after the name of the place where the plot develops. Special attention should be paid to "The Green Road", a chapter where the search for Rosaleen, who has gone astray, and her own reflections on her past alternate and give the reader a complete picture of the current situation. In this second part, Enright presents the concept of Irish family as a construct rather than as an actual practice and, at the same time, uncovers the transformations that Ireland has undergone in the last decades, demonstrating the personal and social consequences of a socially feeble society.

If anything, The Green Road is a fractured novel, as it may be read as a series of short stories, set at different times and places, a form already familiar to the author. ${ }^{3}$ This is a formal strategy that accommodates with "the disruptive and multifaceted condition of Ireland and the Irish" (Estévez-Saá, 2016: 45), where an almost undetectable omniscient narrator, occasionally switched to a familial "we", is combined with the use of a free indirect style to lead the reader through each character's worries, values and feelings. A variety of literary devices that include feedbacks, multilocality, rhythm, etc., are used for the construction of the characters' fragmented identities. Moreover, the distance in time and place among these stories highlights each sibling's experiences and stresses individuality as opposed to collectivity. As the author confessed, the purpose was to juxtapose, "to put one thing up against another" (Rintoul, 2015). The result obtained is twofold: First, the emotional distance between all five members of the Madigan family is enhanced, with each chapter offering a snapshot of the characters' lives. Enright's use of this formal device is very effective to portray what Palese has called "the isolated nomad" (2013: 191), referring to one of the consequences of liquid modernity upon individuals. Collective fragmentation is captured in flashes of individual experiences and this formal disruption provides a kaleidoscopic view of family ties and extenuates the feeling of estrangement. Then, the reader is forced to recreate feelings and situations in order to fill in the gaps and infer a broader picture. Second, it articulates Bauman's scheme on the variability of place and time as a destabilizing combination that prevents the establishment of human bonds. When social aggregation does not function anymore as the main provider of a set of standards and benchmarks for the individual, the subject's notion of identity is blurred (Palese, 2013). In the first part of the novel especially, this aspect is enhanced by both the physical separateness of the Madigan members and by the timespan between their scarce meetings. In sum, Anne Enright's ability to perform a fractured narration in form and content has contributed to considering this novel "probably Enright's most interesting experiment with the genre of the novel to date" (Estévez-Saá, 2016: 52). 
While the national discourse prevalent for the most part of the $20^{\text {th }}$-century Ireland promoted the physical and emotional connection of people to a particular geographical place (Gray, 1999), in contemporary Ireland the nation loses its relevance in favor of other economic factors. So, in The Green Road, territoriality and citizenship are contested through displacement. Mainstream discourses tend to present mobility as a neutral or even positive phenomenon. It is "the revenge of nomadism over the principle of territoriality" in Bauman's words (2000:13). However, other voices claim that this kind of uncontrolled mobility "contributes to decomposing the nation state and the distinctiveness of individual societies" (Fagan, 2003: 111) by eroding the nation-state sovereignty and its citizens' feeling of belonging (Castles, 2002). As a consequence, we can affirm that "the more people move around the world, the more family and community become disembedded" (Inglis \& Donnelly, 2011: 127). Social constructions of belonging, such as family and home, are challenged. Detachment from the roots and its effects in every single character are evident in Enright's novel. It first makes the reader know more about each of the characters than the siblings ever get to know about each other. Through the use of diverse perspectives, Enright alludes to the complexity of human relations as much as to the unreliability of each character. It is as if "each of those children has a separate planet", says the author (Rintoul, 2015). This literary collage, heightened by temporary gaps, is a conscious choice that the writer uses to outline each character's particular form of fragmentation. For instance, Dan's life in the U.S.A. is unpredictable and changeable, always menaced by the AIDS epidemic. In the absence of any other merit of his own, he recites Yeats and enacts the mystique of Irish melancholy, a device that allows him to jump from one gay relation into another. Surprisingly, his status is the opposite in the family context, as the following scene illustrates:

They did not kiss, not in the kitchen, though they would have kissed were they up in Dublin or in any other town. Instead Dan pulled out a chair, and Hanna got up to fill the kettle again. She knew, as the water hit the crusted element, that this was the only place in the world where Dan would sit, requiring tea. In any other kitchen he would serve and smooth and tend. (The Green Road -henceforth TGR, 2015: 216)

For his part, Emmet's wandering around the world working for NGOs is presented as a metaphor of his incapability for love and attachment, a deficiency in harsh contrast to his girlfriend's total devotion for a street dog in a country of starving people. Enright depicts a character who is moved to work for the poor out of duty and conscience rather than genuine love, and who behaves accordingly in his personal life too: "Good, sweet, kind-hearted Alice. Endlessly sweet. [...] He was lucky to have her. But he was not yet sure that you could call it love" (TGR, 2015: 113). Also, Hanna's alcoholism is the result of disappointment in life and age: "She caught sight of her face and thought it was possible, it was more than possible that 
the theatre was finished for her now. [...] And she was thirty-seven. She had run out of time" (TGR, 2015: 194). In Hanna the reader sees a doomed character who is not able to cope with her own life and whose mental sanity is at risk. Moreover, the allusion to tragedy is premonitory in the use of intertextuality, as illustrated by the following paragraph: "That evening, with Hugh blank-eyed, slumped on the sofa, she pawed her way along the living room wall. She pushed her cheek against it and dragged her face along, not sure who she was playing this time. Some madwoman. Ophelia, undone" (TGR, 2015: 193). As a disoriented character, Hanna demands some type of certainty that she has not found in her life: "She had thought there would be a path, one that wound from the school musical all the way up to the red carpet at Cannes. But there was no path" (TGR, 2015: 193). Her lament, more explicit than Emmet's, addresses the uncertainty of liquid modernity whose absence of patterns and norms isolates the individual and increases anxiety when making choices (Bauman, 2007a). Finally, Constance impersonates a well-off housewife who worries over her cancer diagnosis. She tries to mask her apprehension with compulsive consumption behavior developing an ambivalent relation towards her body, a body that she "used to be pleased with" (TGR, 2015: 74) but whose condition does not match the standards anymore. The relation between globalization and body politics (Mackie \& Stevens, 2009) is manifest in her rejection and disgust towards her own body to the point that she "was fed up with herself. And fat, she knew, was a toxic thing" (TGR, 2015: 74). Although Constance is the Madigan sibling who stays at home, she also bears her particular form of fragmentation, i.e., an involuntary detachment from her body. Her character is paradigmatic of the effects of prosperity and represents two sides of the same coin: she blames her body for her looks and her disease but at the same time she is helplessly glutted on the prosperity of Celtic Tiger Ireland.

One of Enright's greatest achievements in this book is the escalation of personal fragmentation to the family level. The enlargement from the personal to the social perspective incorporates a political stance to the plot and confirms the deep structural change that the Irish society is undergoing under the umbrella of globalization. The reader encounters a novel about a fragmented collectivity represented both in the characters' distinctiveness and individualization as much as in the formal way the author presents them. As the following passage illustrates, it is memory rather than shared experiences that links this group of people: "In the place where Constance loved Dan, he was eight years old" (TGR, 2015: 198). In other words, it is the conceptualization of family rather than its actual practice that connects one another. Constance's affection for Dan seems to be restricted to her memories, a paradigm replicable among the rest of the Madigan clan. Through a young Hanna's eyes, the author devotes the first chapter to depict the intricate relations that sustained the family in the 1980s. In Ardeevin, the reader is allowed to walk the different rooms and spaces of the house as the characters' changing moods are presented and their domestic Irish life is depicted. Undoubtedly, the house is the place where these relations take 
form, so after the spread of the siblings, it is the only physical evidence of that former community. While the novel explores the tensions between separation and connection (Clark, 2015: 1), the reader is allowed to enter the intimate universe of the characters and share their subtle affections with their home place. "Home" has been defined as "[...] a whole set of connections and affections, the web of mutual recognition that we spin around ourselves and that gives us a place in the world" (O'Toole, 1997: 136), but the term becomes problematic in the Irish context where migration and homeland have for long been individually and collectively experienced in what Hickman has labelled a "diaspora space" (2012: 23). Accordingly, the family house in The Green Road is the place that embodies memories and meaning to essential notions of self:

It was a question of texture, Dan thought, a whiff of your former self in a twist of fabric, a loose board. It was the reassuring madness of patterned wallpaper under the daily shift of light. The sun rose at the front and set at the back of Ardeevin, wherever he was in the world, and when he came back, the house made sense in a way that nothing else did. (TGR, 2015: 248)

Eventually, the selling of the family home requires that the siblings cannot return, even if it is only mentally, to their roots. Furthermore, it is related to a loss of memories, of mutual recognition, of identity. Thus, the obliteration of "home" both as an ideological construct and as a real place would imply veiled consequences for each character. Their estrangement from their physical and emotional roots would condemn each character to a state of total vulnerability. ${ }^{4}$ It would also make the family, both as a concept and as a performance, dissolve among the waters of globalization and modernity.

\subsection{Material Ireland: afflicted people in a booming country}

It is no coincidence that in The Green Road Anne Enright chooses the housing business as a disruptive pretext to summon the Madigans. In fact, this sector represented over $10 \%$ of Ireland's GPD (gross domestic product) (Smyth, 2012: 133) and more than twice as many units per head of population were built in Ireland by 2007, a frenzy accompanied by phenomenal growth in house prices (Kitchin, O’Callaghan, Boyle, Glesson \& Keavenev, 2012: 1308). Accordingly, the novel portrays this escalation and offers a bleak view of its outcomes: "Emmet looked out the window at the identical house on the other side of the road, alive with fairy lights. Since the money came in, Ireland depressed Emmet in a whole new way. The house prices depressed him" (TGR, 2015: 206). In the light of this passage, one of Anne Enright's accomplishments is the way the novel transcends the material and visual aspects of the real estate boom and engages in the emotional consequences of this phenomenon. As the novel evolves, the reader realizes that in The Green Road no one is 
happy, despite the boom and bust. The role of the family, which was expected to work as a support network, is revealed as a hopeless solution to these personal tragedies. The reader learns that all four children had left the family home long ago, only meeting every odd Christmas. But regardless of their search for happiness elsewhere all of them are injured somehow.

At this point, it is also worth considering this novel's ability to portray the effects of globalization upon those who never left Ireland. These characters feel doomed by the chances they never encountered abroad, and the following passage is illustrative of Constance's frustrations:

If she had gone to New York she would not be worried about cancer now. She would have been jogging for years, living on wheatgrass, she would have a yoga "practice", maybe even a personal trainer, and her children would be -she could not imagine what her New York children would have been like- whiny, at a guess, that mixture of anxiety and entitlement you saw in city kids. Her children would be fewer. Her children would not exist. (TGR, 2015: 87) ${ }^{5}$

At the same time, the author subtly reports the effects that the rapidly changing world is having upon the Irish population: those who stayed during the Celtic Tiger years seem to be as deceived by life as those who left for good. The somber feeling that pervades the novel is indicative of the contradictory demands of globalization. Individuals are encouraged to align with a set of attitudes and expectations that primarily attend to their material welfare. Their level of wealth and notoriousness measures their success in life. Indeed, the novel is written with a subtle irony that succeeds to ridicule the absurdness of consumerism. Enright's critical eye has been sharp enough to reflect Ireland's frenetic economic behavior. As Smyth put it, "Ireland became a bastion of conspicuous consumption" (2012: 132). Indeed, the Celtic Tiger period has frequently been pointed to as an example of how neoliberal policy may turn a relatively poor and peripheral economy into a modern and booming country through a "rapid shift to high-skilled manufacturing, a phenomenal growth in the service sector, the development of a domestic consumer society, a rapid growth in population through natural increase and emigration, and a housing and property boom" (Kitchin et al., 2012: 1302). Culturally, a celebration of materialism has accompanied the economic miracle, especially in media portrayals of contemporary southern Irish society's consumerism (Coulter \& Coleman, 2003: 13). But at the sight of this phenomenon, critical voices (Kirby, 2004; Smyth, 2012) have dismantled the mainstream discourse of prosperity and success aligned with neoliberalism that praised Ireland's economic boom as a model to be followed by other states. Hand in hand with Ireland's GDP growth rates (7.6\% between 1990 and 2001), some negative effects have also been found in terms of unemployment and inequality. As a parody of that fluctuating Celtic Tiger Ireland, the novel entertains several scenes of compulsive 
buying and wastage. On preparing Christmas Eve dinner, the author pictures Constance shopping frantically and determined to buy the most exotic and diverse products, a vivid representation of domestic uncontrolled consumerism:

She got wine, sherry, whiskey, fresh nuts, salted nuts, crisps, bags and bags of apples, two mangoes, a melon, dark cherries for the fruit salad, root ginger, fresh mint, a wooden crate of satsumas, the fruit cold and promising sweet, each one with its own spring of green, dark leaves. (TGR, 2015: 229)

With a touch of irony, Enright depicts a housewife whose feverish compulsion reaches new heights, "The bill came to four hundred and ten euros, a new record" (TGR, 2015: 230), only to discover that she has forgotten the potatoes once she is on the road. Material wealth is so naturally present in the novel that only occasionally do the characters show surprise at a particularly dissipating behaviour:

He turned away and, "Why does everything feel so mad?" she said to Emmet. It's like. I don't know what it's like. Everyone's so.

"I know", said Emmet.

"Showing off".

"It's the money", said Emmet.

"Like everyone's a returned Yank, even if they're living up the road. Hiya, Frank! Home for the duration?". (TGR, 2015: 223)

Although all the Madigans are part of that collective frenzy, it is Constance who best impersonates the "nouveau riche". Thanks to her husband's successful business, she can carelessly fall into uncontrolled domestic consumption:

"Oh I can't remember," she would say when her mother asked the price, or complained about the price. Times were good. Constance bought a wheel of Camembert, various boxes of chocolates, Parma ham and beautiful, small grapes that were more yellow than green. She got her hair done in a place so posh it didn't look done at all. (TGR, 2015: 227)

Amidst these and other comic scenes, Enright also inserts subtle remarks on the social pressure for material wealth to which the population was subjected. As Bauman (2007a) defends, consumerist patters have an impact on identity building, among other aspects. In The Green Road, it is malcontented Rosaleen who best voices a negative perception of her children according to these parameters: "Four children on the brink of middle age: the Madigans had no traction in the world, no substance. They had no money" (TGR, 2015: 240). This mother figure, whose name symbolically addresses Irish nationalism and fidelity 
to the homeland and recalls James Clarence Mangan's ballad "Dark Rosaleen", is used to voice the disintegration of the family unit too, and it is through her words that the transfer of consumerist patterns upon relations between individuals is best detected (Bauman, 2007b). So, despite the country's craze for accumulation, a feeling of failure, a void deep inside is also acknowledged:

They wanted to say that they had money or that they did not need money, but their failure gaped back at them, and they just stood there, looking at it. It was true. They had no money. And yet, and yet. They each struggled to remember this, they had enough. Whatever they wanted, it wasn't this. (TGR, 2015,236)

In fact, what the Madigans want is never said openly. Instead, a feeling of deep dissatisfaction pervades the novel: "Everyone was so disappointed, these days, Constance thought, it was like an epidemic" (TGR, 2015: 93). These "collateral casualties of consumerism" (Bauman, 2007b: 25) are too difficult for these individuals to cope with. As a consequence, Constance takes Seroxat against anxiety and depression while Hanna takes to the bottle. Again, the novel's political stance resides in its overt illustration of how personal afflictions and social frailty are a result of and cohabit with exultation in the economic arena.

\subsection{Vulnerability, old age and human compassion in Celtic Tiger Ireland}

The idea of individual and collective identity fragmentation is aligned with the frailty of the self, a recurring issue in Anne Enright's works (Smith, 2013). In fact, her use of a writing style very close to "interior monologue" (Wood, 2015), allows a deeper and more complex exploration of each character's experience and conforms to Bauman's sociological analysis of the contemporary individual:

Identities seem fixed and solid only when seen, in a flash, from outside. Whatever solidity they might have when contemplated from the inside of one's own biographical experience appears fragile, vulnerable, and constantly torn apart by shearing forces which lay bare its fluidity and by cross-currents which threaten to rend in pieces and carry away any form they might have acquired. (Bauman, 2000: 83)

Accordingly, in The Green Road, all the characters exhibit some form of affliction and disorientation: Dan jumps from one sexual relation to another, Hanna is unable to overcome her addiction to alcohol, Constance keeps her malady a secret, ${ }^{6}$ and Emmet works endlessly to end hunger in the world: "Twenty years saving a world that remained unsaved" (TGR, 2015: 240). It is through her focus on these characters' failures that the author addresses the 
contradictions characteristic of the human condition as much as the devastating effects of globalization.

But the extent of introspection needed to appreciate the characters' intrinsic volatility is masterly achieved in Anne Enright's treatment of Rosaleen's old age. After exhibiting largely her performance as an ineffective nurturer through her children's memories, the novel turns towards her appraisal of her own life and concentrates on her frailties throughout the last pages. As a mother, she feels she has been neglected and left behind by her own children: "These people, who spent their entire time leaving her. Not ringing, not writing. They told her nothing, spent their lives getting out of there. Get out and keep going! That was the cry" (TGR, 2015: 272). This excerpt epitomizes how the author presents family as two opposite concepts. The Irish diaspora is ever-present in the book although it incorporates a new paradigm, i.e., the ravages of globalization. After many years of distant separation, the Madigan children are summoned to see their home put on sale but only at the end of the book is the reader aware of the hidden reasons to sell the house that Rosaleen can only admit to herself: "It was old age, of course -the fear [...] Rosaleen was terrified of losing her mind, of saying things or snapping in public" (TGR, 2015: 264-265). Keeping this biological process a secret must be read as intimately related to globalization because in neo-liberal rationalities aging populations are perceived as a social and economic burden due to their increasing dependency and the subsequent higher public expenditure (Connell \& Pringle, 2004). The concept of vulnerability is associated with globalization benefiting capitalism at the expense of social wellbeing (Keohane \& Nye, 2001; Kirby, 2005 \& 2006; Murphy, 2009). Moreover, this term embodies a twofold dimension: "an increase in threats coupled with a weakening of coping mechanisms" (Kirby, 2006: 636). That mixture of insecurity and vulnerability is what Bauman calls "derivative fear" (2006). The United Nations has also reported that the causes of vulnerability have multiplied over the last decade, in part due to "increased mobility of populations and changes in family structures" (2003: 2), identifying the elderly as one of the affected groups. In the light of the demographic evolution Ireland has undergone in the last decades, aging has become a matter of study in several fields, sociology and literature included (Grau, 2004; Walsh, Carney \& Ní Leime, 2015). Accordingly, in The Green Road, Rosaleen experiences a situation of helplessness accentuated by her children's geographical dispersal, a matter that has affected her experience of family structure to the point that her support network is reduced to her daughter Constance's timely visits. This situation of dependence causes Constance a high level of stress and it makes Rosaleen feel fear and abandonment. Her terror of aging and senility is intimately linked to place and space and she wonders: "where could you put yourself [...] If the world turned into a series of lines and shapes, with nothing in the pattern to remind you what it was for" (TGR, 2015: 165). Under the light of these arguments, the selling of the house may be understood as a desperate move to force her children to shelter her. Thus, despite Rosaleen's blatant inadequacies as a mother, 
at the end of the novel the reader feels compassion for a vulnerable woman in her old age. After all the years she has lived alone, now she sees herself as a fragile human being in need of care: "Because there were gaps between things, and this frightened her" (TGR, 2015: 266). The reader suspects that these lapses have gone unnoticed by Constance and the rest of her siblings. So, it is only when Rosaleen gets lost walking the Green Road that her children are finally able to come to terms with the woman she is at present: "She was an elderly woman in desperate need of their assistance and even as her absence grew to fill the cold mountainside, she shrank into a human being -any human being- frail, mortal, old" (TGR, 2015: 284). Again, Rosaleen's identification with Ireland's impoverished past is metaphorically supported by the abandoned famine cottage where she is finally found but that part of Irish history remains alien to her children.

In sum, old age, the erosion of the family network and the absence of social protection are inferred as the ultimate causes of Rosaleen's vulnerability. To soften the bittersweet taste of an unwanted end, Enright gives the scene a touch of tenderness: "For the moment, Emmet looked at his mother sitting in his pathetic, chipboard kitchen and he was strangely pleased to see her there" (TGR, 2015: 309). Hence, in the end Rosaleen's needs are met with a mixture of compassion and filial duty. She lands in Emmet's apartment for the time Constance has to deal with her treatment against cancer. ${ }^{7}$ Albeit temporary, it is a solution.

\section{CONCLUSION}

Anne Enright's The Green Road is a shattering novel of personal and social fragmentation. In correspondence with the category "liquid modernity" defended by Bauman (2000), Enright addresses the ravages of neo-liberal rationalities upon individuals and its consequences. In the novel, references to material Ireland are embedded in the characters' attitudes and performances to the point that the socioeconomic context of Celtic Tiger Ireland determines the frailty of human bonds and social cohesion.

The novel presents an irrefutable formal innovation in the use of the short story form as isolated chapters in order to reinforce the idea of fragmentation. Through the use of this strategy, the author adds dynamism to the plot and emphases the variability of time and space that characterizes globalization. Enright's kaleidoscopic presentation purposely breaks with a linear view of human lives. Thus, the Madigans' biographies are scattered with voids and the reader is forced to imagine the missing scenes as much as the characters. In The Green Road, temporal and geographical alterations contribute very effectively to the notion of unpredictability and instability.

In terms of content, the novel portrays the deep transformations Ireland has undergone in only a few decades using a family gathering as the central topic of the narrative 
-and confronting the mother figure, linked to the Irish past, to her children's lives, representatives of present-day Ireland. The traditional concepts of family and home displayed in the first chapter are rapidly altered in part as a result of the Celtic Tiger phenomenon: familial ties are substituted by distant and superficial relations. One of Enright's major achievements in this novel may be found in her representation of family disintegration as a form of social feebleness that has its roots in individual fragmentation. In particular, Enright's use of memories as the individuals' main resort to make sense of their notion of family is an accurate strategy to illustrate the frailty of human bonds within the Madigan clan and of this social structure to a larger extent. In the novel, this personal and collective process is intimately related to scenes of uncontrolled consumerism, which are put against passages of personal desolation and helplessness. These contrasts, which sometimes verge on the absurd, are sustained in Bauman's thesis on the effects of globalization upon individuals, who become good consumers but also competitive goods (Palese, 2013). While the novel is a testimony of the Irish buoyant economy, observable in the many passages about the housing business, Enright's denunciation of the contradictions inherent in globalization focuses on their devastating effects upon its characters. These "collateral casualties" (Bauman, 2007b) are skillfully presented through scenes that address different forms of vulnerability: the psychological effects of a gendered body politics, alcoholism, anxiety and old age, among other afflictions. It all makes The Green Road a narrative sprinkled with brief glimpses of compassion that attempt to soften the ravages of neo-liberal rationalities.

In sum, The Green Road is a novel of formal and content innovations that succeeds at mirroring Celtic Tiger Ireland's consequences both upon individuals and society. In doing so, Enright's work incorporates a political stance without judging this phenomenon openly. Quite on the contrary, the novel focuses on the characters' misfortunes, which are directly related to Bauman's interpretation of contemporary society labeled as "liquid modernity" (2000). In the end, the novel offers no answer to any of the personal and social troubles presented, thus leaving the characters and the reader to face unresolved situations. In sum, The Green Road is the record of a buoyant and confident economy, a sample of the complex relations among humans in a rapidly changing world, a world that moves too fast.

\section{NOTES}

1 The Green Road was the winner of the 2015 Irish Novel of the Year, shortlisted for several awards, the 2015 Costa Novel Award among others, and longlisted for the 2015 Man Booker Prize.

2 Nonetheless, emigration never ceased and about 14,000 Irish nationals left annually during the boom period (O'Brien, 2012).

3 Anne Enright has published several collections of stories. The Portable Virgin, published in 1991, won the Rooney Prize for Irish Literature. 
4 The exploration of vulnerability is not new to Enright. Both The Gathering (2007) and the short story "My Little Sister", included in her collection Taking Pictures (2008), have been studied from the position of the narrators as voices excluded from the mainstream discourse (Meaney, 2011).

5 In $20^{\text {th }}$ and $21^{\text {st }}$ century Irish fiction, the USA is presented as a recurrent and idealized destination for Irish women. Usually, these female protagonists' performative degree of agency is limited by the physical boundaries of the homeland. Ireland is perceived as oppressive whereas America is depicted as liberatory. Interestingly, contemporary Irish fiction shows a tendency to look backwards and fictionalize Irish migrants' experiences overseas (Barros-del Rio, 2016; Brewster \& Huber, 2015).

6 The fact that her medical revision is kept a secret entails a private and public problematic relation with the female body as a site of identity construction. This issue has been studied extensively elsewhere (Cahill, 2011; Jeffers, 2002; Meaney, 2010).

7 It is interesting to note how smoothly the novel hints a veiled relation between the politics of care and gender. From a gender perspective, Enright challenges the naturalization of the feminine role of caretaker invalidating Constance temporarily. This circumstance forces Emmet to give an alternative and unusual response masculinizing that role (Yuval-Davis, 2007).

\section{REFERENCES}

Barros-del Río, M.A. (2016). Translocational Irish identities in Edna O'Brien's memoir Country Girl (2012). Gender, Place and Culture, 23(10), 1496-1507. doi: 10.1080/0966369X.2016.1205000

Bauman, Z. (2000). Liquid Modernity. Cambridge: Polity Press.

Bauman, Z. (2006). Liquid fear. Cambridge: Polity Press.

Bauman, Z. (2007a). Consuming life. Cambridge: Polity Press.

Bauman, Z. (2007b). Collateral casualties of consumerism. Journal of Consumer Culture, 7(1), 25-56. doi: $10.1177 / 1469540507073507$

Bauman, Z. (2011). Migration and identities in the globalized world. Philosophy \& Social Criticism, 37(4), 425-435. doi: 10.1177/0191453710396809

Brewster, S. \& Huber, W. (Ed.). (2015). Ireland: arrivals and departures. Volume 5. Wissenschaftlicher Verlag Trier.

Cahill, S. (2011). Irish Literature in the Celtic Tiger Years 1990 to 2008: Gender, Bodies, Memory. Bloomsbury Publishing.

Castles, S. (2002). Migration and community formation under conditions of globalization. International Migration Review, 36(4), 1143-1168. doi: 10.1111/j.1747-7379.2002.tb00121.x

Clark, A. (2015, August 9). Interview: Anne Enright. The Guardian. Retrieved 1 April, 2016 from http://www.theguardian.com/books/2015/aug/09/anne-enright-ireland-is-my-home-but-i-feeli-have-been-trying-to-leave-all-my-life

Connell, P. \& Pringle, D. (2004). Population ageing in Ireland: projections 2002-2021. National Council on Ageing and Older People.

Coulter, C. \& Coleman, S. (2003). The End of Irish History? Critical Reflection on the Celtic Tiger. Manchester: Manchester UP. 
D'Andrea, A., Ciolfi, L., \& Gray, B. (2011). Methodological challenges and innovations in mobilities research. Mobilities, 6(2), 149-160. doi: 10.1080/17450101.2011.552769

Enright, A. (2015). The Green Road. London: Jonathan Cape.

Estévez-Saá, M. (2010). Antidotes to Celtic Tiger Ireland in Contemporary Irish Fiction: Anne Haverty's The Free and the Easy and Éillís Ní Dhuibne's Fox, Swallow, Scarecrow. In D. Clark \& R. Jarazo Álvarez (Eds.), 'In the Wake of the Tiger.' Irish Studies in the TwentiethFirst Century (pp. 199-210). A Coruña: Netbiblo.

Estévez-Saá, M. (2013). Immigration in Celtic Tiger and post-Celtic Tiger Novels. Literary Visions of Multicultural Ireland. In P. Villar-Argáiz (Ed.), The Immigrant in Contemporary Irish Literature (pp. 79-92). Manchester: Manchester University Press.

Estévez-Saá, M. (2016). A Map of Things Known and Lost in Anne Enright's The Green Road. Estudios Irlandeses, (11), 45-55.

Fagan, H. (2003). Globalised Ireland, or, contemporary transformations of national identity? In C. Coulter \& S. Coleman (Eds.). The end of Irish history? (pp. 110-121). Manchester: Manchester University Press.

Fitzgerald, P. \& Lambkin, B. (2008). Migration in Irish History 1607-2007. Basingstoke: Palgrave MacMillan.

Gilmartin, M. \& White, A. (2008). Revisiting contemporary Irish Migration: New Geographies of Mobility and Belonging. Irish Geography, 4(2), 143-149. doi: 10.1080/00750770802076919

Grau, M. V. (Ed.). (2004). The polemics of Ageing as reflected in Literatures. Essays on Ageing in Literature and Interviews with Vikram Chandra, James Halperin, Doris Lessing, Zadies Smith and Terri-ann White. Volume 3. Universitat de Lleida.

Gray, B. (1999). Longings and belongings-gendered spatialities of Irishness. Irish Studies Review, 7(2), 193-210. doi: 10.1080/09670889908455634

Hanafin, P. (2001). Constituting Identity: Political Identity Formation and the Constitution in Postindependence Ireland. Ashgate Pub Limited.

Hand, D. (2011). A History of the Irish Novel. Cambridge: Cambridge University Press.

Hickman, M.J. (2012). Diaspora Space and National (Re)Formations. Éire-Ireland, 47(1), 19-44. doi: 10.1353/eir.2012.0009

Inglis, T. \& Donnelly, S. (2011). Local and national belonging in a globalised world. Irish Journal of Sociology, 19(2), 127-143. doi: 10.7227/IJS.19.2.9

Jeffers, J. (2002). The Irish Novel at the End of the Twentieth Century: Gender, Bodies and Power. New York, NY: Palgrave.

Kennedy, F. (1989). Family, Economy, and Government in Ireland (No. 143). ESRI.

Keohane, R. O. \& Nye, J.S. (2001). Power and Interdependence. ( $3^{\text {rd }}$ ed.). New York, NY: Longman.

Kirby, P. (2004). Globalization, the Celtic Tiger and social outcomes: is Ireland a model or a mirage?, Globalizations, 1(2), 205-222. doi: 10.1080/1474773042000308578

Kirby, P. (2005). Globalization, vulnerability and the role of the state: lessons for Ireland. Administration, 52(4), 49-68. doi: 10.1080/1474773042000308578

Kirby, P. (2006). Theorising globalisation's social impact: Proposing the concept of vulnerability. Review of international Political Economy, 13(49), 632-655. doi: $10.1080 / 09692290600839915$ 
Kitchin, R., O'Callaghan, C., Boyle, M., Gleeson, J., \& Keaveney, K. (2012) Placing neoliberalism: the rise and fall of Ireland's Celtic Tiger. Environment and Planning, 44(6), 1302-1326. doi: $10.1068 / \mathrm{a} 44349$

Mackie, V. \& Stevens, C. S. (2009). Globalisation and body politics. Asian Studies Review, 33(3), 257-273. doi: 10.1080/10357820903153699

Mays, M. (2005). Irish Identity in An Age of Globalisation. Irish Studies Review, 13(1), 3-12. doi: $10.1080 / 0967088052000319472$

McGlynn, M. (1999). "But I keep on thinking and I'll never come to a tidy ending”: Roddy Doyle's useful Nostalgia. Lit: Literature Interpretation Theory, 10(1), 87-105. doi: 10.1080/10436929908580235

Meaney, G. (2010). Gender, Ireland and Cultural Change: Race, Sex and Nation. London: Routledge.

Meaney, G. (2011). Waking the Dead: Antigone, Ismene and Anne Enright's Narrators in Mourning. In C. Bracken \& S. Cahill, S.(Eds.). Anne Enright (pp. 145-164). Dublin: Irish Academic Press.

Morales-Ladrón, M. \& Elices Agudo, J.F. (Eds.) (2016). Family and Dysfunction in Contemporary Irish Narrative and Film. Oxford: Peter Lang.

Murphy, M. (2009). What impact might globalisation have on Irish civil society? In P. Kirby \& D. O'Broin (Eds.). Power, Dissent and Democracy: Civil Society and the State in Ireland (pp. 34-48). Dublin: A\&A Farmer.

O'Brien, D. (2012, March 22). Irish Emigrating a fact of life but not as bad as it could be. The Irish Times. Retrieved 1 April, 2016 from: http://www.irishtimes.com/opinion/irish-emigration-afact-of-life-but-not-as-bad-as-it-could-be-1.486595.

Örmengül, S. (2015). Postnationalist Subversion of the Constituents of Irishness: Land, Religion and Family in the Plays of Martin McDonagh and Dermot Bolger. Doctoral dissertation, Middle East Technical University, Turkey. Retrieved 12 September, 2016 from http://fle.metu.edu.tr/node/216

O'Toole, F. (1997). The Ex-Isle of Erin: Images of a Global Ireland. Dublin: New Island Books.

Palese, E. (2013). Zygmunt Bauman. Individual and society in the liquid modernity. SpringerPlus, 2(1), 191. doi: 10.1186/2193-1801-2-191

Rintoul, C. (2015, August 4). Anne Enright-The Green Road-Bookbits author interview. Youtube. Retrieved 12 October, 2016 from https://www.youtube.com/watch?v=PTjuJ1bQ-IM

Smith, M. (2013). Subjectivity as Encounter: Feminine Ethics in the Work of Bracha LichtenbergEttinger and Anne Enright. Hypatia, 28(3), 633-645. doi: 10.1111/j.1527-2001.2012.01300.x

Smyth, G. (2012). Irish national identity after the Celtic Tiger. Estudios Irlandeses, 7, 132-137.

United Nations. (2003). Report on the World social Situation: Social Vulnerability: Sources and Challenges. New York, NY. United Nations Department of Economic and Social Affairs.

Walsh, K., Carney, G. M., \& Ní Leime, A. (Eds.). (2015). Ageing through austerity: critical perspectives from Ireland. Policy Press.

White, T. J. (2008). Redefining Ethnically Derived Conceptions of Nationalism: Ireland's Celtic Identity and the Future. Studia Celtica Fennica V, 83-96.

(C) Servicio de Publicaciones. Universidad de Murcia. All rights reserved. IJES, vol. 18 (1), 2018, pp. 35-51 Print ISSN: 1578-7044; Online ISSN: 1989-6131 
Wood, J. (2015, May 25). All her Children. Family Agonies in Anne Enright's The Green Road. The New Yorker. Retrieved 1 November, 2016 from: http://www.newyorker.com/magazine/2015/05/25/all-her-children

Yuval-Davis, N. (2007). Nationalism, belonging, globalization and the ethics of care. Kvinder, Køn \& Forskning, 2-3, 91-100. 